\title{
Legislation, Projects and Strategies for the Implementation of Educational Inclusion in Italy: Results, Questions and Future Prospects
}

\author{
Francesca Gobbo ${ }^{*}, 1$, Roberta Ricucci ${ }^{*}$ and Francesca Galloni ${ }^{2}$ \\ ${ }^{1}$ Dip. Scienze Educazione e Formazione, via G. Ferrari 9/11, 10124 Torino, Italy \\ ${ }^{2}$ Dept. of Social Sciences, Via S. Ottavio 50, 10124 Torino, Italy
}

\begin{abstract}
The chapter presents the contemporary changes taking place in the Italian school population and the policies of integration addressing the educational needs of immigrant pupils and minority ones, such as the Roma. After discussing the situation of non Italian pupils, the authors synthetically describe the Italian legislative framework regarding the right to education and focus on the role of intercultural education in governing change in schools' multicultural contexts. Since the 1970s, Italian educational legislation and policies have supported an integrated model within the Italian school system and have extended it to the above mentioned groups of pupils in the last twenty years, promoting and implementing inclusion processes rather than segregation. It has been deemed relevant to include reflections on bullying, because integration of non Italian students continues to be a matter of concern and often Italian pupils isolate or discriminate foreign children.

Furthermore, the authors warn about the risk of a culturalist perspective at the basis of inclusion projects, that paradoxically seems to entail a "naturalization" of cultures and languages, and point out how ethnographic research provides findings and interpretations that are able to counteract such a trend.
\end{abstract}

Keywords: Italy, educational inclusion, intercultural legislation and practices.

\section{INTRODUCTION}

Italian legislation aimed to substantially widen school inclusion which started to be promoted in the 1970s and regarded disabled pupils and students in particular. The 1970s was a decade when educational discourse and action also emphasized the need for effective right to education and greater democratic participation, that was realized by a Parliament vote in favour of having parents becoming members of the newly established school councils in order to discuss and decide with teachers about school matters.

Today, what challenges schools' organization as well as teachers' expectations and educational competences is a school population comprising non Italian pupils and students: their inclusion and quality of educational experience raise the concern of educationists and the need to monitor both goals closely. How Italian legislators, local administrators, schools principals and teachers respond both in terms of learning opportunities and provisions, as well as of conflict control, to what apparently continues to be perceived as the momentous turn of Italy from a country of emigration to one of immigration (more than twenty-five years after migrants began to enter the country's work sectors) will be presented here and discussed.

*Address correspondence to these authors at the Dip. Scienze Educazione e Formazione, via G. Ferrari 9/11, 10124 Torino, Italy; Tel: +39 011670 3241; Fax: +39 0116703165 ;

E-mails: francesca.gobbo@unito.it, galloni.francesca@libero.it, and

Dept. of Social Sciences, Via S. Ottavio 50, 10124 Torino, Italy; E-mail: roberta.ricucci@unito.it,

\section{FOREIGN PUPILS AT SCHOOL}

Statistics on non Italian school population collected by MIUR indicate its steady increase with respect to the total school population, even though the current economic and work crisis begins to see a number of immigrant families return to their home country. According to the data of the Ministry of Education, in school year 2009-2010, non Italian pupils and students were 673,592 and accounted for $7.5 \%$ of total school population (Fig. 1) [1]. However, the following features continue to characterize those youth's educational experience: [1] the structural dimension of foreign pupils' increase in the Italian school system [2], its uneven distribution across the country [3], its growth concerning mostly vocational and technical schools at the upper secondary level [4], the number of schools and urban neighborhoods whose classrooms are predominantly composed of foreign pupils.

Speaking about immigrant pupils at Italian schools, it is necessary to face the problem of their generational definition. In fact, until now, the majority of them arrived in Italy for family reunion. This means that their age at the time they left their country acquires significance. In fact, unlike the second, Italian-born generation, foreign adolescents born elsewhere share with their parents their country of origin, language and culture, although they differ in other aspects. Therefore, how can we define these adolescent minors who have certain characteristics that would compare with first generation migrants and yet are projected - and partly socialized - within a context different from where they were born and partially grew up? Some Italian authors use the definition of the ' 1.5 ' generation [2]. 
As mentioned above, the number of foreign minors has increased in the Italian education system, stressing the deep structural and socio-cultural changes in Italian society. In the last twelve years, the number of foreign students has become almost ten times greater, with a 50,000 unit yearly increase during the last three years. This is a distinctively Italian situation: this rate is not comparable with other countries where the "transformation" took a longer time.

The school is the best observatory to study the development and numerically growth of foreign young generations. Through this channel, it emerges clearly how the most important difference between immigrant and native children is the migratory biography. The age at the moment of immigration determines ethnic differences in educational attainment among migrant pupils. The explanation is based on the logic of a generation-integration-cycle implying that the generation status determines the education career. Following this hypothesis, children starting primary school and having attended kindergarten in the host society (namely the second generation) have higher opportunities of ending up with higher educational qualifications. Those arriving after the age of twelve are more likely to leave school without having obtained a high school level diploma. This is clearly shown in the experience of a recent immigration country - like Italy - where migrant pupils are overrepresented among " 1.5 " generation (i.e. children rejoining their family between 10 and 14 years old). Consequently, studies based on recent Italian experience have found that there is a lack of inclusion of immigrant children in the school environment and that national students need to be supported to adapt to the arrival and inclusion of immigrant students.

The generational factor is not the only one to take into account when the Italian school context is considered. In fact, another difference with other immigration countries is the so-called polycentrism (i.e. the presence of a number of different nationalities within the classrooms). This is a peculiar element which intervenes in the daily life of schools, where school principals and teachers have to develop strategies for managing a plethora of different sociolinguistic backgrounds in each classroom. This situation is not spread even by all Italian schools: the phenomenon of foreign pupils' concentration in a few schools is well-known, especially in specific areas of the major Italian cities (Milan, Rome, Turin, Florence). Nevertheless, the growing up of a second generation adds a new element to this scenario: schools have - in the meantime - developed projects which address both to foreign pupils newly arrived in Italy and those who are born in Italy, to 1.5 generation and 2.0 generations.

Some efforts have been made to better understand characteristics and profiles of foreign students. Three examples clarify this attention. Firstly, in the last two years, statistics on students enrolled in Italian schools split foreign students according to their place of birth, stressing the growth of the second generation.

This distinction is necessary to guarantee proper educational opportunities to those newly arrived from outside and to those who follow a wholly-Italian school path, which does not however mean that they do not need particular attention. In the latter situation, we find above all infant-school and primary-school children, while in later stages of education the proportion of foreign-born pupils is even greater.

Secondly, since 2008, the definition of "New arrivals in Italy" has been introduced to identify foreign students enrolling in Italian schools from abroad (e.g. due to family reunification) [3]. If these two novelties suggest a positive attention in order to better define school programs for a more complex school population, bearing in mind the different school paths, the variety of educational backgrounds and the lack of competences among teachers in facing multicultural classes, in the meantime one controversial question arriving on the school agenda this year also stresses education debates: it is the separation of children without sufficient knowledge of the language of instruction into special classes

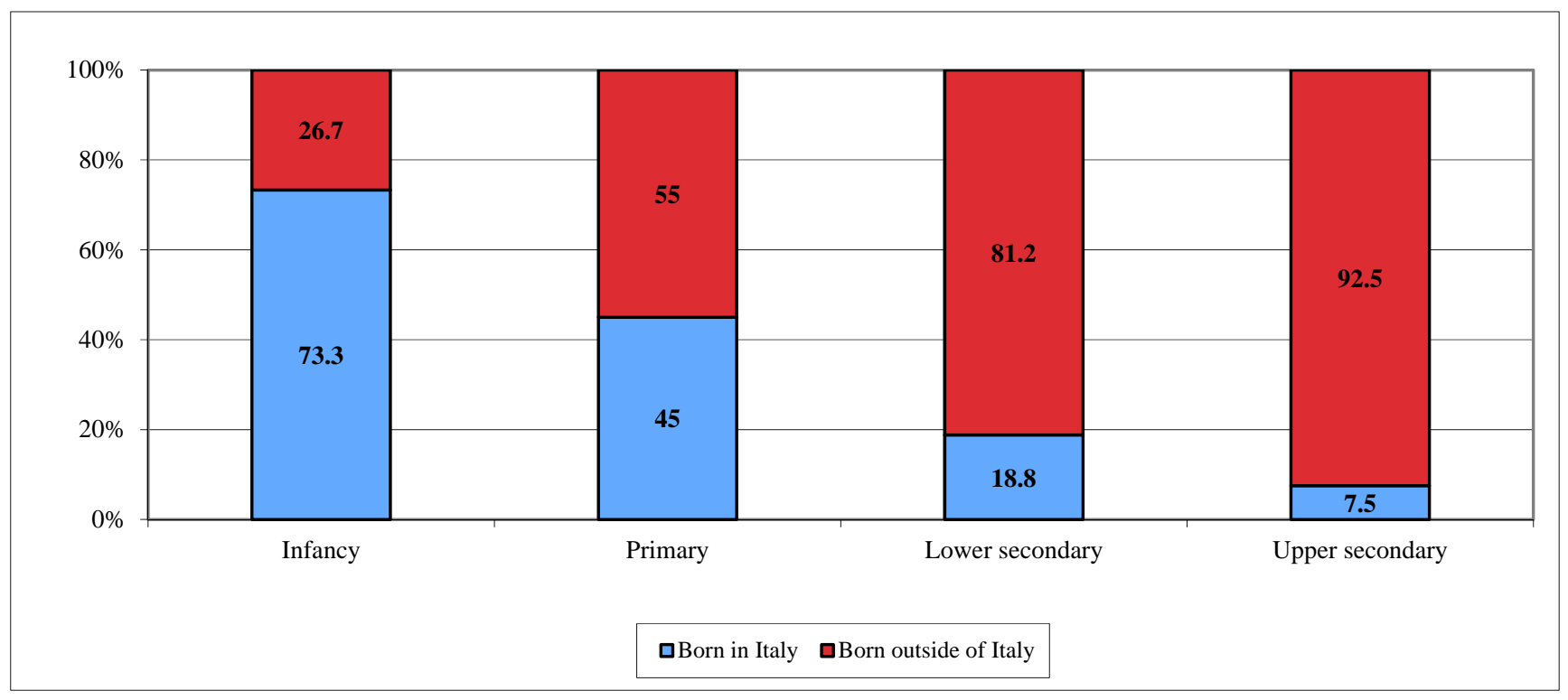

Fig. (1). Pupils with non Italian citizenship by birthplace and school level. [s.y. 2008-09 (\%)]. Source: [3]. 
for foreigners. Scholars criticizing this model add the argument that without contact with native pupils the probability of acquiring the language of the host country is reduced. Furthermore, schools where immigrant children are taught in the same class as the native population offer better opportunities for inter-ethnic contacts among students. Third, the new law provision, Circular of Ministry of Education $\mathrm{n}$. 2 , 8.1.2010, provides for a maximum of $30 \%$ of foreign students in the classrooms.

\section{FOREIGN STUDENTS AT THE CORE OF THE RESEARCH AGENDA}

The birth-rate of the second generations (the children born in Italy from first-generation immigrants) is increasing, but at the moment it is mainly represented by children under 10 years old. Since the early 2000s, however, as already mentioned above issues have broadened and measures have deepened to improve the attention and increase the importance of the field. Local and regional studies (see references) have helped to identify key topics of interest to researchers and to educators, but unfortunately this research has not helped to redirect and improve policy and practice: changes in policies and improvements in practices appear to be fragmented. More attention has been dedicated to the school area. Several works [4-8] investigated the social characteristics of immigrant children and their difficulties with the Italian school and language. Classrooms and schools are governed by linguistic, socio-cultural and social interaction codes that may well diverge from those governing the home, peer and community lives of foreign pupils. Language and literary acquisition, in particular, may be impeded when the social organization of teaching and learning ignores these differences, and fails to provide opportunities and activities that permit students to integrate in the classroom and proceed in their schooling. This is the reason why schools are beginning, on the one hand, to define projects addressed to foreign pupils' parents, recognizing the strategic importance of family involvement for student success. On the other hand, networks with NGOs and intercultural associations have developed to support foreign students' educational paths $[9,10]$.

Two surveys have compared results and educational preferences of foreign pupils with those of their Italian peers. The first [11] was carried out in 1998, in nine Italian cities, and the second one [12] was carried out more recently, in 2007, and concerned ten Italian regions. The data collected in the two research studies show a high degree of similarity between the sample groups in their perception of one's school achievements, educational and work preferences, family relations and future expectations. Nevertheless, other studies $[13,14]$ continue to show how there is a lack of inclusion of immigrant children in the school environment as well as that national students need to be supported to adapt to the arrival and inclusion of immigrant students. These studies noted that immigrant children encounter hostility and difficulties at school. But, what are the key issues with regard to minority pupils at school? Looking at the relationship between school and immigrant pupils, the most important lesson emerging from the Italian case is the importance of supporting youth integration programs concentrating on the following core areas: language acquisition, education, integration into the labor market, social counseling and social integration.

Attention to migrant pupils, or those belonging to an ethnic minority, especially at lower secondary school level,

has been acknowledged as crucial for the definition of integration paths. In fact, it is exactly at this level that the bases for subsequent schooling are built: without language support, an educational basis, etc. foreign minors arriving from abroad when 11 to 14 years old risk pursuing exclusively vocational education.

With particular reference to language, it is seen among the first criteria considered when allocating immigrant children to mainstream classes: the question Italian teachers deem crucial for that purpose is "are those children capable of following lessons in the language of instruction used at schools?"

With regard to the school success of non-Italian pupils and students, the family socio-economic condition continues to be an important factor of school success or failure. According to this, in Italy there are till today significant differences between both the North and the South of the country and between residential areas and the peripheries in the main cities. In these specific contexts, firstly, low educational and low economic capital of the parents has a negative effect on the school careers even of Italian children. Within the Italian context too, adolescents with a poor family background mainly attend institutions because these are considered as less educationally and culturally demanding and more useful to job placement [15]. In this situation, the network of external survival support for the elaboration of one's migratory experience, combined with the adolescents' crisis stage, is poor. Often, the second generation has neither people to whom they can express uneasiness, worries and difficulties nor places where they can do it. The socioeducational world in general seems still unprepared to tackle - and even notice at times - the specific relevance of diversity and of cultural, religious and family feelings of belonging during these adolescents' growth process. In these conditions, adolescents' growth processes can increase intergenerational gaps and negatively affect assimilation and integration paths.

To sum up some data dealing with the most recent Italian sociological studies: first, for immigrant pupils at risk of school failure for whatever reason, it is feasible to hypothesize that these young people grow up in a context characterized by the lack of strong identification models. The family is weak because, in most cases, it holds a marginal position in society (low capital and socio-economic status) as well as not possessing the cultural tools useful for promoting school paths and the success of their children.

Second, there is a scarcity of external aid, essential for survival, combined with adolescent crises and the process of elaborating one's own school and society experience. Often, the pupils at risk do not have models or places where they can express discomfort, worries and problems.

Finally, there often is, in the socio-educational world, inadequate support, which seems still ill-equipped for the management of the continuous challenges facing 
adolescents, especially those living in the suburban and socio-economically deprived areas. In these conditions, their growing process can increase the generational gap and negatively influence school and socio-integration paths.

\section{INTERCULTURAL EDUCATION AND THE ITALIAN SCHOOL SYSTEM: HOW TO UNDERSTAND AND ADDRESS THE CHANGE.}

From the early 1980 s, when Italy realized that it was slowly becoming a country of immigration, the Italian Ministry of Public Education distanced itself from either an assimilationist stance on, or a "special case" approach to the schooling of immigrants' children. In fact, the administrative documents (circolari, circulars), the paragraphs in legislation about migration, as well as solemn statements (Pronuncie) all resonate with the recommendations issued at the European level, and particularly by the Council of Europe (CoE). The latter had supported, in the 1970s, the right of those pupils and students (who at the time were mostly from Southern European nation states) to learn the language and culture of origin (Taylor 1997); in the 1980s, CoE had urged that migrants should be recognized as cultural subjects and not only as labor force, and that diversity - be it cultural, linguistic, religious or ethnic - should be made the focus of educational attention and the motor of a new educational perspective, namely intercultural education.

Intercultural education interprets diversity as an asset and an educational resource rather than as a trait to be ignored or silenced as it usually happens (and did happen in the past) when social actors and institutions, such as schools, are not prepared to engage with it in order to understand what is distinctive and what is common to the partners of the intercultural encounters. Thus, if the early Italian circolari recognized the right of immigrants' children to their cultural and linguistic distinctiveness, the 1994 one widened the educational scope by subscribing to intercultural education. The latter was, and is presented as a discourse and actions that favor comparison between different perspectives on, and meanings of life, and promote interaction and conversation (or dialogue, as it is suggested by the 2008 Council of Europe's White Paper on Intercultural Dialogue) as the main educational tools to achieve and maintain understanding and respect among people living in complex, multicultural societies.

The Italian educational perspective shared from the beginning the belief that fostering a process of reflective and critical appraisal both of others' diversity and of one's own identity is an effective way to be aware of, to question, and eventually overcome stereotypes and prejudices with which diversity is too often confronted, and identity is protected. While recognition of diversity may challenge the sense of an "imagined" national unity and membership, and in turn makes the host country's citizens react against being culturally open, it provides the opportunity for taking stock of the changes and for debating how to build an inclusive social cohesion and participation. According to many Italian educationists, intercultural education has also given policy makers and teachers the occasion to bring the country's internal diversity to the fore, to reflect on how, historically, such cultural and religious diversity is (and was) defined and treated, and to stress that the intercultural perspective addresses both the present heterogeneous school population and Italian democratic society as a whole. In this vein, intercultural education is consistently presented as the educational "horizon" of school and society in Italian policy documents issued in the 2000 s, or as "a twenty year long narrative" by intercultural experts such as Vinicio Ongini and Claudia Nosenghi [16].

The 2006 document entitled Linee guida per l'accoglienza e l'integrazione degli student stranieri (www.miur.it) traces the history of, and the different ways in which intercultural education was presented to, disseminated among teachers: in 1989 it was defined as "an answer to problems of foreign/immigrant students" especially with regard to learning Italian and valorizing the immigrants' language of origin. However, a year later intercultural education was seen as the "principle of involvement of Italian students in an interaction with foreign/immigrant students so as to pursue mutual enrichment". The authors of a 1993 statement added that intercultural education also is "the highest and global form of prevention and opposition" to racism and every other form of intolerance, and argued for the need to problematize the meaning of diversity by seriously considering the Italian and European memories of historical intolerance and racism.

The widening of the meaning and scope of intercultural education in Italian educational documents is also explained in relation to the changes in European politics and decisions: the Maastricht Treaty established the conditions to go beyond the notion of an European Economic Community and towards the European Union - a step Italy supported firmly. Thus, the vision of a Europe where enhanced mobility can multiply the opportunities for intercultural encounters resonates in the 1998 immigration law where intercultural education projects are promoted that aim to valorize cultural and language differences as well as to support initiatives for welcoming students into their new schools and for cultural exchanges. The 2005, 2006 and 2007 documents (www.miur.it) confirm these educational indications, and provide further pedagogic suggestions to avoid the risk that the earlier strong educational commitment for "inclusion" be diluted or contested (for the debate on the issue of citizenship, cfr. [17]).

\section{EDUCATIONAL PROVISIONS FOR A NEW SCHOOL POPULATION}

The institutional response has been to give way to, and sustain, a number of "good practices" aimed to:

- Support migrant pupils' school integration (through language courses, cultural mediators' support, leaflets explaining the characteristics of the Italian school system, translation of educational materials);

- $\quad$ Improve the relationship between schools and migrant families. Furthermore, the organization of training courses has been enhanced for teachers to develop new methodologies and define new tools and ways to teach in a multicultural classroom.

Given the legislation earlier mentioned, quite a number of research projects or activities (see the following table) are enacted at the regional and local level, both by regional and 
local government bodies and by non-governmental organizations. The recent revision of Article $\mathrm{V}$ of the Italian Constitution (voted in 2001) has favored such partnerships, by introducing a form of school decentralization and autonomy that allows schools to independently devise part of their educational offer, and become more responsible for their educational choices as well as more responsive to local needs.

\begin{tabular}{|c|c|}
\hline 1 Initiatives for teachers in... & \\
\hline $\begin{array}{l}\text { Empoli, Pistoia, Bologna and } \\
\text { Turin }\end{array}$ & $\begin{array}{l}\text { Courses, projects and meetings } \\
\text { aimed at widening and deepening } \\
\text { educational competence. }\end{array}$ \\
\hline \multicolumn{2}{|l|}{ Initiatives for migrant pupils in... } \\
\hline Veneto Region & $\begin{array}{l}\text { Actions aimed at fostering Italian } \\
\text { language proficiency, both for } \\
\text { young people and for lifelong } \\
\text { learners. }\end{array}$ \\
\hline Lombardy Region & $\begin{array}{l}\text { Through the "Progetto } \\
\text { Intercultura", Cariplo Foundation } \\
\text { funds and organizes many events } \\
\text { and projects around the year since } \\
\text { the early nineties. }\end{array}$ \\
\hline Arezzo province (Tuscany) & $\begin{array}{l}\text { Intercultural education projects } \\
\text { (especially Italian as a second } \\
\text { language and foreign students' life } \\
\text { stories collected at the upper } \\
\text { secondary education level). }\end{array}$ \\
\hline Turin & $\begin{array}{l}\text { "Se non ora, quando?" ["If not } \\
\text { now, when?"], project aimed at } \\
\text { supporting and reinforcing } \\
\text { processes of inclusion of foreign } \\
\text { citizens so that their integration be } \\
\text { promoted. }\end{array}$ \\
\hline $\begin{array}{l}2 \text { Research projects focused on } \\
\text { investigating migrant pupils' } \\
\text { school integration in... }\end{array}$ & \\
\hline $\begin{array}{l}\text { Research in Cremona on Sikh } \\
\text { children }\end{array}$ & $\begin{array}{l}\text { This research offers an innovative } \\
\text { interpretation of school integration } \\
\text { processes and obstacles } \\
\text { experienced by those students. }\end{array}$ \\
\hline $\begin{array}{l}\text { Research on out of school - } \\
\text { initiatives in Turin and in Mazara } \\
\text { del Vallo }\end{array}$ & $\begin{array}{l}\text { These researches have shown the } \\
\text { importance of supporting migrant } \\
\text { pupils in their leisure time, helping } \\
\text { them in the integration process both } \\
\text { at school and in the Italian society. }\end{array}$ \\
\hline $\begin{array}{l}\text { Research in Turin both on pupils } \\
\text { and teachers }\end{array}$ & $\begin{array}{l}\text { The research is aimed at describing } \\
\text { whether or not the Italian schools } \\
\text { are well equipped for receiving } \\
\text { migrant pupils and in which way } \\
\text { the school integration process of } \\
\text { these pupils is proceeding. }\end{array}$ \\
\hline
\end{tabular}

Gobbo F., Ricucci R., Galloni F. eds. Inclusion and education in European countries. "Final report: Italy". Lepelstraat: DOCA Bureaus, August 2009.

As it can be seen, more than $90 \%$ of the initiatives in the North-Centre of Italy are developed through a partnership among local authorities, school, NGOs and associations (both intercultural and ethnic). This kind of partnership highlights one of the main characteristics of the Italian educational/migration scenario: as compared with a limited number of institutional (i.e. ministerial) initiatives, there is a great self-promotion of associations and the third sector.
They satisfy the needs of schools and pupils with "just in time" interventions, that are however somewhat fragile: they are carried out under annual funding, without either any continuity or any final evaluation of the efficacy of the actions. Recently, some projects funded by local authorities require a final evaluative report that however consists of a self-declaration written by the grantee organization, without any evaluation carried out by experts.

Organization of courses for school principals, administrative staff, future teachers and in-service teachers is considered as urgently desirable and indispensable (and some have in fact already taken place) so as [1] to recognize and answer the different needs of a diverse school population [2], to become responsible for new educational initiatives in line with the official perspective of "school autonomy" and a "bottom up" educational approach, and [3] to mobilize itself around such initiatives.

However, the educational inclusion of non Italian pupils and students - as Fondazione Agnelli (2010) points out continues to be matter of concern, mainly owing to the fact that [1] the official rule of enrolling them in the grade corresponding to their age is not always honored; [2] their school delay grows significantly with age and school grade and level and it may indicate schools' partial inability to meet pupils' educational needs; [3] there is a risk of strengthening and disseminating stereotypical views of other cultures (often at the origin of incidents of social uneasiness and/or bullying, see [10, 18-21], and of ignoring the interesting changes within those groups, as it has been stressed by ethnographic research.

\section{FOREIGNERS: BULLIES OR VICTIMS?}

With regard to further strategies for supporting schools and teachers in order to avoid exclusion, marginalization and isolation of pupils and students, it is worth mentioning that a detailed overview of extensive research literature on bullying, as well as of the guidelines issued by the Ministry of Education and of specific and various initiatives and associations against bullying, indicate that anti-bullying programs will not be as effective as they could be, if they are not accompanied (or even anticipated) by preventive actions and analysis of the nature of conflicts. The need to intervene in emergency situations or concern for solving conflicts, though necessary, may not be sufficient to understand actions that are, or are perceived as aggressive and abusive and whose complex reasons require a close attention (see [22]).

Studies of bullying began in Italy in the 1990s and they are numerous, but rarely speak of "racist" bullying. Often Italian studies present the various traits of bullies and victims, but do not specify the causes of these traits or explain whether the phenomenon is affected by national, cultural, religious or other differences.

Even when the title of an essay implies cultural diversity [23], what constructs the outcast is drug addiction and the problem is blamed on the kids. Specific contributions have been made about bullying that targets homosexuality [24], while there seems to be a dearth of publications that deal solely with the theme of bullying immigrants. 
Rarely are there any explicit references to the types of diversity that most likely trigger episodes of bullying: for example Menesini [25] notes that bullying often occurs against minority groups, "other ethnicities" and disabled persons. Menesini speaks of "racist" bullying that includes racial slurs and social isolation of the bullied person (idem). Likewise Castorina [26] mentions the link between bullying and racism but research data on this aspect are hard to find. Even in cases where a correlation is made, it seems to be only hinted at, and not demonstrated or interpreted. Thus, in the study on bullying [27] that focuses on different types of bullying, most answers indicated ridicule or slander. As one of those responses is indicated as "due to skin color", we can therefore presume that bullying occurs against non-Italian students and that since such episodes usually take place at school, among classmates, we can hypothesize that the contact theory is disproved.

By using stories Buccoliero [28] introduces the theme of bullying from different point of views, and also points out cases where there may be a connection between bullying and immigration. For example, in one of the stories we meet Amina, a young Albanian girl, who helps a victim of bullying because she remembers having been ridiculed as a foreigner. Another story describes a boy from Costa Rica adopted by an Italian family. His story starts in the present (with the psychological adversity and the drug addiction), and then leads us to the bullying behavior of his past.

More specifically, we must admit that it is not difficult to find multiple references to the deviance of foreign kids [9, 29-32]. In this regard Omodeo [9] further notes that the perception of bullying differs according to whether the bully is Italian or foreign, and that native Italians are presumably better able than non Italians to hide their behavior.

Though not much attention is given to bullying against immigrant minorities, Italian studies show that much Italian literature about immigration stresses the relational difficulties between Italians and non-Italians. Researchers indicated the several difficulties confronted by bullied youth: some results from their isolation in after-school activities, that in turn makes it difficult for them to observe and properly interpret the rules of informal gatherings [33-37], or from cultural [38], or linguistic reasons [39]. Isolation is increased by the tendency to stay within one's own ethnic group or a culturally homogeneous circuit [33, 40-44], and residential segregation is one of the reasons for this.

There are studies that show positive interaction, as in the case of the teachers interviewed by Censis [45]: they believe that relations between foreign and Italian students and between foreign students are usually good or satisfactory. Yet ethnographic research and experiences as a psychologist confirm the presence of discrimination and bullying against non-Italian students. In particular, participant observations in schools (both at primary and secondary level) and in extrascholastic structures show cases of exclusion: some Italian students isolate the foreign ones or tease them by claiming that they are $<<$ black $>>$, or that they $<<$ stink $>>[21,36,46$, 47].

Saulini [48] points out that the United Nations Committee has expressed concern for the increase in bullying in Italian schools and notices that the integration indicators of foreign minors are based mainly on scholastic achievement, while relations between students, and between students and teachers, are given little importance. So the Workgroup for the Rights of Children and Adolescents [48] promotes the use of integration indicators that take into account not only scholastic achievement and linguistic competence but also relationships in the classroom. Consequently, research is urgently necessary to understand the actual situation and avoid improvizing an appropriate response.

Recently, and at the institutional level, more attention has been given to bullying immigrants in Italy. The Ministry of Public Education (Protocol No. 5843/A3 Rome of 16 October 2006) rightly connects the more general issue of promoting legality and democracy with a multicultural and intercultural perspective and indicates the need to extend the meaning of citizenship. Yet we believe that the relations between students in the formal educational context and in the extra-scholastic structures are the foundation of all strategies for implementing social inclusion [49].

\section{THE CONTRIBUTION OF ETHNOGRAPHY FOR PROMOTING EDUCATIONAL INCLUSION}

In relation to the risk of strengthening and disseminating stereotypical views of other cultures, and of ignoring the interesting changes within those group (as mentioned by point 3 of paragraph 4), ethnographic research carried out in school and out-of-school contexts seems to be especially qualified to monitor the cultural changes and agency enacted by the immigrants' children. By paying close attention to their "voices", ethnography is able to effectively question their image as "carriers of cultures" that are too often seen as homogeneous and essentialized, on the one hand, and, on the other, to signal how the cultures and organization of schools - as well as of out-of-school places - can turn inclusive policies into excluding and labeling provisions [50]. This last point is especially relevant for minority group members such as the Roma, many of whom are Italian citizens or hold the status of refugees. Because of the European institutions' great concern for Roma children's educational inclusion, schools and teachers initial and in-service training as well as Roma pupils' school experience have been placed under scrutiny, on the one hand, and, on the other, they have been offered recommendations and opportunities for implementing "good practices". In this light, it is appropriate to refer to projects funded by the European Commission (for details, see [51]). They are highly relevant to the process of educational inclusion as they are precisely devoted to promote inclusion of non Italian and Roma pupils and students, and to improve both the latter's learning and their teachers' relations with families, and they were successfully completed. Thus, for instance, the results of the INSETRom training course in Turin (see www.iaie.org/insetrom) as well as in Florence are especially satisfactory due to the involvement of teachers, and the quality of researchers' and experts' teaching [52-55], while the national meeting on the schooling of Roma children - recently organized by the 
Ministry of Education - saw a high participation by committed teachers and school leads ${ }^{*}$.

In fact, intercultural education, and its practices, can benefit from the probing and questioning of the multiple facets of diversity in schools by ethnographers and through theories of anthropology of education [56]. Multicultural educational contexts, and the extent to which processes of cultural communication (or miscommunication), cultural understanding (or misunderstanding), comparison or conflict are realized or fail, represent an opportunity for an interdisciplinary approach that can account for the maintenance of a cultural orientation or, on the opposite, for the acquisition of new ones. Therefore, in Italian heterogeneous classrooms, many ethnographic inquiries have been carried out on

1. The various aspects of diversity, and its problematic relation to education and migration [10, 18, 57-65],

2. Representations of multicultural classrooms, and of the processes of teaching and learning occurring there [21, 36, 37, 66-73],

3. Out-of-school contexts and interactions, where young people's agency and projects become visible [44, 7476],

4. The controversial learning experience of Roma pupils [61, 77-94].

With regard to the socio-cultural changes already mentioned, it must be underlined how, in the 1990s, a number of cultural anthropologists generously answered the concerns and questions about culture, ethnicity, identity that arose from teachers of multicultural classrooms. Through writings and lectures those anthropologists aimed to provide the intellectual tools for making sense of diversity and for becoming aware of the risk of cultural reification. Yet, they seldom considered multicultural educational contexts as relevant for ethnographic fieldwork that was instead promoted by educational researchers eager to study learning and teaching processes within the framework of anthropological theories of education, and firmly convinced that ethnographic research can be a form of intercultural encounter ante litteram [61, 95].

In this perspective, ethnography is seen as a methodological approach that is crucial, if not indispensable, for singling out the taken-for-granted - and ethnocentric assumptions on which schooling, and even intercultural education, are founded, and for seeing pupils and students (and teachers and families as well) as actively involved in (not always successful) relational and learning strategies [18, $71,72]$, as able to gauge the social and educational situations $[21,36,73]$ and to evaluate them in terms of cost-benefit analysis [37], as well as to meet the challenges of the host society by investing in new cultural and social learning [44, $75,76,96]$. Furthermore, the educational focus on diversity might lose its educational relevance and effectiveness unless schools and teachers discuss, and critically appropriate, the anthropological attention for, and the debate on culture and identity. In this way they will also be able to contest the

\footnotetext{
*Seminar promoted by Ufficio Regionale per la Lombardia on Roma children "Bambini rom, alunni rom. Scuola, lingue, culture", Gardone Riviera, 18-19-20 October 2010.
}

current, and worrying, tendency towards the "naturalization" of cultures and languages that instead requires a thorough, critical exploration [97-99] of the return of biological interpretations of diversity, even when they aim to positively stress the mixing of people and cultures $[100,101]$.

\section{CONCLUSIONS: POSSIBLE COUNTER-INCLUSION MECHANISM}

Many studies and news projects show how hard it is to create social cohesion and inclusion, especially in recent years when forms of underage hardship and discrimination and racism against young people have multiplied [49]. Reacting to this situation means becoming involved in a meaningful challenge, being concerned about the human capital of the next years. In Italy, a part of the human capital consists of the children of immigration, with whom children of Italian descent share the classroom, where tomorrow's Italian society is being formed in embryo. Once more school is the right starting-point for reflecting on how, using what tools and professional skills, to help the young generations become active citizens, socially inclusive and respectful of various differences.

The Italian case shows that there are contexts in the process of activating positive collaboration, using the various links of the education network to lead this youth in the three facets of the growing process: training, identity recognition and integration. Educational programs external to the school perform a key role, especially with regard to the integration in a "positive" peer group. Transversal to school time and free time are youth workers, associations (both ethnic and intercultural), parishes and NGOs continuing to play a significant role in the Italian scenario but whose role, when performed within the integration perspective, could be helpful for parents on one hand, and on the other hand, for teachers, in decoding those identity dynamics, that are a potential source of inter-generational conflict and of antisocial behavior.

As is already clear from references to research and official documents, in Italy the education system has chosen the integrated model (children are allocated to classes consisting of children of the same age in mainstream education). However, given the scarcity of resources available for specific language workshops for foreigners, every school tries to manage this problem independently. The use of multi-media tools can be a more appealing way for students to approach a new language.

Finally, we must keep in mind that no action can ignore a combined effort between the different actors working in the free time and the family, which often the youngsters consider as a deprived (different from infancy) and disappointing place (not as rich and well settled as previously hoped for) that nevertheless remains the place for daily interaction, rules and moral position.

So, in order to improve the integration of foreign children and youth into different school system, it is considered useful to: 1) design specific sub-policies (sub-practices) aimed at the different immigrant groups; 2) better support foreign families and promote the potentially crucial role they play in furthering their children's education: in this way an initiative could contribute to avoid the risk of reproducing exclusion over generations in a knowledge-based society and 
of stabilizing stratifications along ethnic lines; 3) establish initiatives at local level promoting the positive interaction between pupils of different origin and the process of secondary socialization to tolerance, pluralism and democratic values.

\section{ACKNOWLEDGMENT}

Francesca Gobbo, is author of the introduction and sections 3, 4, 6 and 7. Roberta Ricucci is author of sections 1, 2 and 7. Francesca Galloni is author of section 5 .

\section{CONFLICT OF INTEREST}

None declared.

\section{REFERENCES}

[1] Caritas / Migrantes. Immigration. Statistical Dossier 2010; Rome: IDOS - Study and Research Centre 2010 [In Italian].

[2] Rumbaut R. Assimilation and its Discontents: Between Rhetoric and Reality. Int Migrat Rev 1997; 31(4): 923-60.

[3] Italian Ministry of University and Research. Students without Italian citizenship. State and private schools 2007/2008 school year. Rome: Italian Ministry of University and Research 2009 [In Italian].

[4] Giovannini G, ed. Students in class, foreigners in the city Research on primary school teachers towards immigration. Milan: Franco Angeli 1996 [In Italian].

[5] Fravega E, Queirolo Palmas L, eds. Young mestizo classes. Students, teachers in schools of migration. Rome: Carocci 2003 [In Italian].

[6] Mantovani D. Second generation at the roll call. Students and secondary schools in Bologna. Bologna: Istituto Cattaneo 2008 [In Italian].

[7] Ravecca A. Study notwithstanding. Social capital and school success of immigrant students in high school. Milan: Franco Angeli 2009 [In Italian].

[8] Giovannini G, ed. Students in class, foreigners in the city. Milan: Franco Angeli 1998 [In Italian].

[9] Omodeo M. The multicultural school. Rome: Carocci 2002 [In Italian].

[10] Gobbo F. Moving Lives, Changing Schools: with regard to Italian Travelling Attractionists, In: Danaher P, Kenny M, Remy Leder J, eds. Changing Schools: International Studies of Traveller and Nomadic Education. London: Routledge; 2008; pp. 13-28.

[11] Giovannini G, Queirolo Palmas L, eds. A school together. Educational experiences in Italian multicultural contexts. Turin: Fondazione Agnelli, 2002 [In Italian]

[12] Casacchia O, Natale L, Paterno A. Studying together, grow together? A survey of second generation in ten Italian regions. Milan: Franco Angeli, 2008 [In Italian].

[13] Luciano A, Demartini M, Ricucci R. Education after compulsory schooling. What courses for foreign students? In: Zincone G, editor. Migration: integrating signals health, school and home. Bologna: Il Mulino, 2009; pp. 113-56 [In Italian].

[14] Eve M, Ricucci R, eds. Young and land routes of integration of young Italians and foreigners in certain provinces of Piedmont. Turin: Proud 2009 [In Italian].

[15] Besozzi E, Colombo M. Young foreigners in Lombardy between present and future. Motivations, experiences and expectations in education and vocational training. Milan: ISMU 2007 [In Italian].

[16] Ongini G, Nosengo C. A class in color. Milan: Vallardi 2009 [In Italian].

[17] Ricucci R. Italian half. Young immigrants grow. Bologna: Il Mulino 2010 [In Italian].

[18] Gobbo F. Pupils step? The narratives of the teachers on the education of children of traveling attractions. In: Gobbo F, ed. Educational processes in multicultural societies. Rome: CISU 2007; pp. 139-59 [In Italian].

[19] Gobbo F. Between the road and the town: the education of travelling attractionists. An ethnographic research. In: Pink WT, Noblit GW, eds. International Handbook of Urban Education. Dordrecht Springer 2007; pp. 481-503.
[20] Committee Against Racism. Differentiation and concentration of foreign pupils in schools in Turin [Research reports]. Turin: Committee Against Racism 2006 [In Italian].

[21] Galloni F. Young Indians in Cremona. Success stories. Rome: CISU 2009 [In Italian].

[22] Galloni F. Bullying. In: Gobbo F, Ricucci R, Galloni F, eds Inclusion and education in European countries "Final Report: Italy. Lepelstraat: DOCA Bureaus, August 2009.

[23] Pinto G, Pistacchi P, Malvagia S. When the "others" meet "different": a study on mental representations. In: Fonzi, editor. The cruel game. Studies and research, and its psychological correlates of bullying. Florence: Giunti 1999; pp. 84-104 [In Italian].

[24] Galvani A, ed. Bullying, homosexuality, and a bit 'indifference. Material for the promotion of respect for homosexuals and the prevention of anti-gay bullying. Verbania: Agedo 2005 [In Italian].

[25] Menesini E. Bullying at school: the nature and characteristics of the phenomenon. In: Menesini E, ed. Bullying: effective actions at the school. Trento: Erickson 2003; pp. 11-26 [In Italian].

[26] Castorina S. Fantasy of bullying. Milan: Franco Angeli 2003 [In Italian].

[27] Safety networks against violence and in favor of legality, Association "With the family for children rights", Piedmont Region, Research on bullying. Available from www.dors.it [In Italian]

[28] Buccoliero E. Normal. Bullies, victims, spectators. Molfetta (BA): La Meridiana 2006 [In Italian].

[29] Istituto degli Innocenti. The daily exception. Report on childhood and adolescence in Italy. Rome: Government Printing Office and Mint 2006 [In Italian].

[30] Eurispes Telefono Azzurro. Seventh national report on childhood and adolescence. Summary of the report. Milan: Graphic Arts Press Fiorin, drafting at No. Annex VITA 49. 2006 [In Italian].

[31] Russo M. School autonomy investee In: Multiplier-CDRTT oeaI, ed. Participation and Solidarity in school. Loneliness and bullying, research report, Avaialable from www.liguri.org 2001; pp. 81-3 [In Italian].

[32] Prina F. Forms of juvenile delinquency. Normal paths of lawlessness and violence, two research projects in Turin. Turin: Sonda 2000 [In Italian].

[33] Cologna D, Breveglieri L, eds. Children of immigration. Research on the integration of young immigrants in Milan. Milan: Franco Angeli 2003 [In Italian].

[34] Bertozzi R. Sociality and experiences outside of school. In: Giovannini G, ed. The condition of foreign minors in Italy, available from www.ismu.org, Ministry of Education, University and Research, Ismu 2004; pp. 124-48 [In Italian].

[35] Valencia LI, Flores PB. Passing through the urban spaces between inclusion and exclusion. In: Queirolo PL, Torre A, Eds. The Phantom of the bands. Genoa: Fratelli Frilli Editore, 2005; pp. 13560 [In Italian].

[36] Galloni F. Ethnography: methodological choice and more. In: Gobbo F, Ed. The search for a school that will change. Padova: Imprimitur 2007; pp. 21-42 [In Italian].

[37] Galloni F. Sikh students in front of the secondary school. In: Gobbo F, editor. Education in the intercultural era. Rome: Carocci 2008; pp. 29-47 [In Italian].

[38] Lagomarsino F. The gaze of adults, including removal, alarm and recognition. In: Queirolo Palmas L, Torre A, editors. The Phantom of the bands. Genoa: Fratelli Frilli Editore 2005; pp. 85-100 [In Italian].

[39] Ricucci R. '1.5' Generation. Strategies of identity and integration paths between family and leisure. Polis 2005; XIX (2): 233-61 [In Italian].

[40] Colombo E. Navigating between differences: the management of the processes of identification among the young children of immigrants. In: AA.VV., ed. Foreigners and Italians. Rome: Donzelli Editore 2005; pp. 83-121 [In Italian].

[41] Quadrelli E. Consumption and social exclusion. Ethnographic research. Fravega E Queirolo Palmas L, ed. Rome: Carocci 2003 [In Italian].

[42] Ambrosini M, Queirolo Palmas L, ed. Latinos discovering Europe. New areas of migration and citizenship. Milan: Franco Angeli, 2005 [In Italian].

[43] Pozza F, Ravecca A. Through space and want: education, training and protected circuits. In: Queirolo PL, Torre A, Edi. The Phantom 
of the bands. Genoa: Fratelli Frilli Editore, 2005; pp. 101-33 [In Italian].

[44] Dallavalle C. Multiple identities: the second generation of Mazara del Vallo. In: Gobbo F, Ed. Education in the intercultural era. Rome: Carocci 2008; pp. 73-89 [In Italian].

[45] Censis. Experiences and outcomes of schooling of children of immigrant origin in Italy Summary of the results. Rome: Censis Foundation, 2008 [In Italian].

[46] Galloni F. Peer group and young Sikhs. Young migrants' learning about young Italians culture. European Conference on Educational Research (ECER) September 11-12; Geneva 2006.

[47] Galloni F, Naclerio L. The afternoons of the second generation: youth looks and educational intention in centers of aggregation of Cremona and Padua. "The second educations. School, training, society," Trickster Review of the Master in Intercultural Studies www.trickster.lettere.unipd.it. 2009, 7 (June 2009) [In Italian].

[48] Saulini A, ed. The rights of children and adolescents in Italy. Third update report on the monitoring of the Convention on the Rights of the Child in Italy 2006-2007 [In Italian].

[49] Galloni F, Ricucci R. Growing up in Italy. Milan: Unicopli 2010 [In Italian].

[50] Gobbo F, Ricucci R. Clasroom segregation? No, thanks'. Reflections from the Italian case. In: Bakker J, Denissen E, Peeters $\mathrm{D}$, et al. eds. International perspectives on countering school segregation. Antwerp-Aperldoorn: Garant 2010; pp. 211-26.

[51] Gobbo F, Ricucci, R, Galloni, F. Inclusion and education in European countries. Final report: 7. Italy. Lepelstraat: DOCA Bureaus 2009.

[52] Gobbo F. Foreign pupils' education and intercultural education: policy making in Italy between 1982 and 2007. Interpreting and governing the change. ECER; Sept. 26-28; Vienna 2009.

[53] Gobbo F. INSETRom in Bolognesi I. (ed) Roma, Sinti and Gage: culture, educational processes and rights, special issue of Educazione Interculturale. 2009; 7: 347-58 [In Italian].

[54] Gobbo F. INSETRom: a European project for the inclusion of Roma pupils in multicultural classes. Madrugada. 2010; 77 (March): 10-1 [In Italian].

[55] Gobbo F, Peano G. A European project for Roma pupils' educational inclusion. ECER Sept. 26-28; Vienna 2009.

[56] Gobbo F. Intercultural pedagogy. The pedagogical project in complex societies.. Roma: Carocci 2000 [In Italian].

[57] Bargellini C. Intercultural communication: Italian language teaching to adult foreigners in Gobbo F, Tommaseo Pinzetta M, eds. Padova: Imprimitur 1999 [In Italian].

[58] Dore G. But here isn't a good party'. The reconstruction of the feast of mutton in the context of migration. In: Gobbo F, ed. Multiculturalism and interculturalism. Padova: Imprimitur 2003; pp. 57-81 [In Italian].

[59] Schmidt D, Palutan G. Narration and representation of immigrant communities in an Italian city. in Gobbo F, ed. Multiculturalism and interculturalism. Padova: Imprimitur 2003; pp. 109-21 [In Italian].

[60] Gobbo F. There is a carousel in the future? School experience and process of inculturation in a nomadic minority employment. In: Gobbo F, ed. Ethnography of education in Europe Persons, contexts, methodological issues. Milan: Unicopli 2003; pp. 209-45 [In Italian].

[61] Gobbo F. Cultural Intersections: the life story of a Roma cultural mediator. Eur Educ Res J 2004; 3: 626-41.

[62] Gobbo F. Along the Margins, Across the Borders: Teaching and Learning among Veneto attrazionisti viaggianti. E Antelitz, P Coombes, P Danaher (Eds) Marginalised Pedagogues? International Studies of the Work and Identities of Contemporary Educators Teaching 'Minority' Learners. Special issue of "Teaching and Teacher Education". 2006; 22(7): 788-803.

[63] Gobbo F. Between the road and the town: the education of travelling attractionists. An ethnographic research. In: Pink WT, Noblit GW, eds. International Handbook of Urban Education. Dordrecht: Springer 2007; pp. 481-503.

[64] Rapanà F. The Albanians of Macedonia in Cembra Valley: an ethnographic investigation. In: Gobbo F, ed. The search for a school that will change. Padova: Imprimitur 2007; pp. 69-91 [In Italian].

[65] Sidoti S. Schools as possible along the way of Travellers Noto. In: Gobbo F, editor. Educational processes in multicultural societies. Rome: CISU, 2007; pp. 191-207 [In Italian].
[66] Ferrari E. The spaces of imagination and irreverent irony in a third average of Quarto Oggiaro. In: Gobbo F, Gomes AM, eds. Ethnography in educational contexts. Rome: CISU 2003; (1st ed. 1999) pp. 261-90 [In Italian].

[67] Gobbo F, Gomes AM, eds. Ethnography in educational contexts. Rome: CISU 2003 [In Italian].

[68] Naclerio L. The uncommon sense of the school. Anthropology of reference and educational models in multicultural kindergarten. In: Gobbo $\mathrm{F}$, ed. Educational processes in multicultural societies. Rome: CISU 2007; pp. 125-36 [In Italian].

[69] Pallotti G. Socialization and learning a second language. In: Gobbo F, Gomes AM, Eds. Ethnography in educational contexts. Rome: CISU. $1^{\text {st }}$ ed. 2003; pp. 185-222 [In Italian].

[70] Peano G. Ethnographic narrative and emotional balance. In: Gobbo F, ed. The search for a school that will change. Padova: Imprimitur 2007; pp. 93-114 [In Italian].

[71] Sansoé R. Children of immigration: from immigrant families were born and raised in the Italian school. In: Gobbo F, ed. The search for a school that will change. Padova: Imprimitur 2007; pp. 115-40 [In Italian].

[72] Galloni F. Young Sikhs among Italians. Gobbo F, ed. Educational processes in multicultural societies. Rome: CISU 2007; pp. 85-100 [In Italian].

[73] Galloni F. Sikh students in Cremona. In: Gobbo F, editor. The search for a school that will change. Padova: Imprimitur 2007; pp. 43-68 [In Italian].

[74] Caronia L. Language and daily life as learning environments. An ethnographic study on socialization to reading in an educational institution. In: Gobbo F, Gomes AM, eds. Ethnography in educational contexts. CISU Rome 2003; (1st ed. 1999) pp. 223-59 [In Italian].

[75] Costa C. Experiencing the meeting: young migrants and Italians in extra-school educational center. In: Gobbo F, ed. Educational processes in multicultural societies. Rome: CISU 2007; pp. 101-23 [In Italian].

[76] Galloni F. What drives the Sikh families to choose a center of aggregation? In: Gobbo F, ed. Education in the intercultural era. Rome: Carocci 2008; pp. 91-107 [In Italian].

[77] Gomes AM. A survey of the ethnography of the school: the education of children Sinti in Bologna. In: Gobbo F, ed. Culture/Interculture. Padova: Imprimitur 1997; pp. 81-108 [In Italian].

[78] Gomes AM. Ethnography and intercultural education. In: Gobbo F, ed. Intercultural Culture. Padova: Imprimitur 1997; pp. 109-37 [In Italian].

[79] Gomes AM. "Vegna che ta fago scriver" Ethnography of schooling in a Sinti community. Rome: CISU 1998 [In Italian].

[80] Gomes AM. Experiences of schooling of Sinti children: comparison of different methods of management of the school day. In: Gobbo F, Gomes AM, eds. Ethnography in educational contexts. Rome: CISU 2003; (1st ed. 1999) pp. 292-331 [In Italian].

[81] Gomes AM. School and schooling. Anthropologia 2004; IV (4): 163-74 [In Italian].

[82] Lelli S. Pragmatic school interaction in a multicultural class with Roma pupils, Microetnografia in a school in Florence. In: Saletti Salza C, Piasere L, eds. Italia Romanì. Rome: CISU, 2004. pp. 22958 [In Italian].

[83] Menchinelli S. The report of a Roma community Kalderasha with the school. Quaderni di Sociologia. 2004; XLVIII (36): 31-49 [In Italian].

[84] Piasere L. The Roma in the Italian school: resistance, reinterpretations, successes. Quaderni di Sociologia. 2004; XLVIII (36) :3-6 [In Italian].

[85] Piasere L. Roma, Sinti, Travellers in Italian schools: results of a research project of ethnography of education. In: Gobbo F, editor. Educational processes in multicultural societies. Rome: CISU 2007; pp. 161-72 [In Italian].

[86] Pontrandolfo S. A century of school. The Roma of Melfi. Rome: CISU 2004 [In Italian].

[87] Pontrandolfo S. In search of the Roma in Melfi: the imagined Roma and repository school. Quaderni di Sociologia. 2004; XLVIII(36): 51-72 [In Italian].

[88] Pontrandolfo S. Invisible Roma in the school context of Melfi. In: Gobbo F, editor. Educational processes in multicultural societies. Rome: CISU 2007; pp. 209-22 [In Italian]. 
[89] Saletti SC. Children of the "gypsy camp". Bosnian Roma in Turin. Rome: CISU 2003 [In Italian].

[90] Saletti SC. There is nothing to laugh about. Management strategies of the school-day of some Roma pupils. Quaderni di Sociologia 2004; XLVIII (36): 7-29 [In Italian].

[91] Saletti SC. Frequency and school profile of the xoraxané Bosnian Roma pupils in Turin. In: Gobbo F, ed. Educational processes in multicultural societies. Rome: CISU 2007; pp. 173-89 [In Italian].

[92] Saletti SC. Roma and Sinti pupils, subjects of a 'special', differentiating path. In: Gobbo F, editor. Education in the intercultural era. Rome: Carocci 2008; pp. 109-28 [In Italian].

[93] Trevisan P. Stories and lives of the Sinti of Emilia. Rome: CISU 2005 [In Italian].

[94] Tuozzi C. Autobiography of experience in the Roma world. In: Saletti Salza C. Piasere L, Eds. Italia Romanì. Rome: CISU 2004; pp. 259-86 [In Italian].
[95] Gobbo F. The teacher as ethnographer: ideas for research training. In: Favaro G, Luatti L, eds. Interculture from A to Z. Milan: Franco Angeli 2004 pp. 126-35 [In Italian].

[96] Costa C. Intercultural friendships in the context of school: an ethnographic study in Turin. In: Gobbo F, ed. Education in the intercultural era. Rome: Carocci 2008; pp. 49-72 [In Italian].

[97] Buiatti M. The benign disorder of life. Turin: Utet 2004 [In Italian].

[98] Barbujani G. The invention of race. Milan: Bompiani 2006 [In Italian].

[99] Barbujani G, Cheli P. I'm not racist, but I'm trying to quit. RomaBari: Editori Laterza, 2008 [In Italian].

[100] Gallissot R, Rivera AM, eds. Cultural pluralism in Europe. Bari: Dedalo Editore 1995 [In Italian].

[101] Gennai G. Intercultural lexicon. Bologna: EMI 2005 [In Italian].

Received: January 26, 2010

Revised: March 14, 2011

Accepted: March 25, 2011

(c) Gobbo et al.; Licensee Bentham Open.

This is an open access article licensed under the terms of the Creative Commons Attribution Non-Commercial License (http://creativecommons.org/licenses/by-nc/ 3.0/) which permits unrestricted, non-commercial use, distribution and reproduction in any medium, provided the work is properly cited. 